Article

\title{
Green Synthesized Silver Nanoparticles of Myrtus communis L (AgMC) Extract Inhibits Cancer Hallmarks via Targeting Aldose Reductase (AR) and Associated Signaling Network
}

\author{
Abdulwahab Ali Abuderman ${ }^{1}$, Rabbani Syed ${ }^{2,3, *}$, Abdullah A. Alyousef ${ }^{4}$, \\ Mohammed S. Alqahtani ${ }^{2}$, Mohammad Shamsul Ola ${ }^{5}$ and Abdul Malik ${ }^{2,3}$ \\ 1 Basic Medical Science Department, College of Medicine, Prince Sattam Bin Abdulaziz University, \\ Al-Kharj 16278, Saudi Arabia; a.abuderman@psau.edu.sa \\ 2 Department of Pharmaceutics, College of Pharmacy, PO Box 2457, King Saud University, Riyadh 11451, \\ Saudi Arabia; msaalqahtani@ksu.edu.sa (M.S.A.); abdul.ksu@gmail.com (A.M.) \\ 3 Nano medicine Research unit (MNU), Pharmaceutical department, college of pharmacy, King Saud \\ University. Riyadh 11451, Saudi Arabia \\ 4 Department of Clinical Laboratory Science, College of Applied Medical Sciences, King Saud University, \\ Riyadh 11451, Saudi Arabia; abalyousef@ksu.edu.sa \\ 5 Department of Biochemistry, College of Science, King Saud University, P.O. Box 2455, King Saud University, \\ Riyadh 11451, Saudi Arabia; shamsulola@gmail.com \\ * Correspondence: rsyed@ksu.edu.sa
}

Received: 17 October 2019; Accepted: 11 November 2019; Published: 18 November 2019

check for updates

\begin{abstract}
In this current study, we demonstrated the green synthesis and characterization of silver nanoparticles using Myrtus communis L. plant extract (Ag-MC) and its evaluation of anticancer and antimicrobial activities. The green synthesis of (Ag-MC), was assessed by numerous characterization techniques such as ultraviolet-visible spectroscopy (UV-VIS), Fourier-transform infrared spectroscopy (FT-IR), X-ray powder diffraction (XRD) transmission electron microscopy (TEM) and energy dispersive $x$-ray spectroscopy (EDX). The anti-cancer activity of the green synthesized silver nanoparticles was evaluated by the median inhibitory dose $\left(\mathrm{IC}_{50}\right)$ on human liver carcinoma cell lines (HepG2). These results suggested that SN-NPs can be used as effective anticancer cell lines, as well as antibacterial and antiseptic agents in the medical field. This study showed that overexpression of aldose reductase (AR) in the human liver carcinoma cell line, HepG2, was down regulated by administration of SN-MC. The down regulation of AR was associated with abrogation of Pl3k/Akt, ERK and NF-kB pathways and the inhibition of cancer hallmarks, however, the target molecule for Ag-MC was not practically established. Thus it is still unknown if the consequences were due to AR inhibition or direct Ag-MC interaction with AR.
\end{abstract}

Keywords: Myrtus communis L.; green synthesis; silver NPs; anti-cancer

\section{Introduction}

The size and morphology of synthesized metallic nanoparticles can be controlled with chemical reducing agents [1-3]. However, the reducing agents and solvents used in the synthesis of nanoparticles are hazardous or toxic to the environment [2]. Consequently, the green synthesis of nanoparticles is anticipated, even though there are a several categories of green reductants (based on isolation/extraction sources) existing in nature. Under these circumstances, green chemistry approaches can significantly assist with the preparations of metal nanoparticles [2]. In recent times, the tendency to use natural materials such as microorganisms [4], marine organisms [5], proteins [6,7], and plant extracts (PE) 
used in the green synthesis of metallic NPs has attained significant consideration in the scientific community $[2,8]$. Especially metal nanoparticles synthesis using plant extracts has been given more attention due to plants being easily available, inexpensive, environmentally friendly and also the ability to highly reduce the usage of toxic solvents or reducing agents [9-11].

Medical plants and their extracts were used as traditional treatments for several diseases in various parts of the world for many thousands of years [12], particularly in rural areas of these countries, they were used as a primary source of medicine [13]. In developing countries, $80 \%$ of the population use natural products in routine health care practice [14].

Myrtus communis L. (family: Myrtaceae) plant is most widely used as medicinal drug in unani medicine since earliest historical times in Greece $[15,16]$. It is a herb with rich contents of flavonoids, alkaloids, tannins, terpenoids and saponins-the biologically active ingredients used in traditional and alternative medicine [15] — which makes it attractive for the green synthesis of silver nanoparticles. It is known as Aas and its berries are recognized [17]. Several investigations revealed that Myrtus communis L. possesses therapeutic and pharmacological effects showing anti-cancer, anti-microbial, anti-diabetic properties, as well as neuro and hepato proactive activity [15-18]. Myrtus communis L. leaves, berries and essential oils are commonly used for several disorders like ulcers, gastritis, rheumatism, diarrhoea, haemorrhages, dysentery, vomiting, deep sinuses, leucorrhoea and in hair loss control [15]. The leaves, berries and twigs are used in flavoring food and wines [19]. In earlier times, ripe fruits were utilized as food integrators due to their rich constituents of vitamins [20]. The present study summarizes green synthesis of silver nanoparticles using Myrtus communis L. plant extract (Ag-MC) and its anticancer effect on human liver carcinoma cell lines (HepG2), and determines the molecular mechanism underlying the modulatory effects of SN-MC on key molecules involved in survival signaling.

\section{Materials and Methods}

\subsection{Materials}

The Myrtus communis L. plant extracts which widely exist in the southern zone of Saudi Arabia, were procured from a local herbal market at Batha, Riyadh, Saudi Arabia. The identity of the plant was confirmed by an expert plant biologist and the details were recorded in our research laboratory. $\mathrm{AgNO}_{3}$ $(99.8 \%)$ and other solvents utilized in this study were procured from Sigma Aldrich, St. Louis, MO, USA. Oligonucleotides primers were purchased from Sigma Genosys, USA. Primary and secondary antibodies were purchased from cell signaling technology and Santa Cruz, USA.

\subsection{Preparation of Plant Extract}

Initially, the fresh aerial parts of Myrtus communis L. were cut into tiny parts. The resulting tiny parts ( $500 \mathrm{gms})$ were soaked in $2.5 \mathrm{~L}$ deionized water and refluxed at boiling temperature for $6 \mathrm{~h}$. The resultant aqueous solution after reflux was separated and dried up at 50-60 ${ }^{\circ} \mathrm{C}$ underneath reduced pressure in a rotary evaporator to give a dark brownish colored extract ( $40 \mathrm{gms})$. Furthermore, the separated extract was kept refrigerated at $0-4{ }^{\circ} \mathrm{C}$ for further use.

\subsection{Synthesis and Characterization of Silver Nanoparticles using Myrtus communis L. Plant Extract (AgMC)}

The synthesis of silver nanoparticles was carried out by combining $1 \mathrm{~mL}$ of Myrtus communis $\mathrm{L}$. extract with $0.5 \mathrm{mM}$ silver nitrate $(85 \mathrm{mg})$ in $49 \mathrm{~mL}$ deionized water in a $100 \mathrm{~mL}$ round bottomed flask. The reaction mixture was stirred with a magnetic bar for $\sim 2 \mathrm{~h}$ at $90{ }^{\circ} \mathrm{C}$ under refluxed conditions with a cooling condenser. During the reaction process, the reaction mixture color changed slowly from light yellow to dark brown. Afterwards, no color transformation was noticed till the completion of the reaction after two hours. Then, the reaction mixture was subjected to a cool down period, and later, the reaction mixture was centrifuged at $8000 \mathrm{rpm}$ at room temperature. Subsequently, the product 
attained from the centrifugation was washed several times (three to four times) with deionized water. After that, the product was dried overnight at $80^{\circ} \mathrm{C}$ in an oven and finally a black powder was obtained.

The as-synthesized silver nanoparticles were characterized by ultraviolet-visible spectrophotometry (UV-Vis spectroscopy, Perkin Elmer lambda 35 (Waltham, MA, USA)), high resolution transmission electron microscopy (HRTEM) and energy dispersive X-ray spectroscopy (EDX) (JEM 2100F (JEOL, Tokyo, Japan)), and FT-IR spectroscopy (Perkin Elmer 1000 FT-IR spectrometer). The powder XRD data were carried out on a Rigaku Mini-flex X-ray diffractometer (Japan) with Cu Ka radiation $\left(\mathrm{k}=1.5418 \mathrm{~A}^{\circ}\right)$ at $30 \mathrm{kV}$ and $15 \mathrm{~mA}$ with a scanning rate of $0.05 / \mathrm{s}$ in 20 in the range from 10 to $90^{\circ} \mathrm{C}$.

\subsection{Cell Lines and Cell Cultures}

Human liver carcinoma cell line (HepG2) were cultured in Dulbecco's modified eagle medium (DMEM) containing 7\% fetal bovine serum (FBS) and $1 \%$ antibiotics (penicillin and streptomycin), maintained under a humidified chamber at $37{ }^{\circ} \mathrm{C}$ with $5 \% \mathrm{CO}_{2}$ supply. Monolayer cells were subcultured frequently and dispensed into a new flask. For each experiment exponentially grown cells were used.

\subsection{MTT (3-4,5 dimethylthiazol-2,5 diphenyl tetrazolium bromide) Assay: Anticancer Activity of Ag-MC}

The anti-cancer activity of the green synthesized M. communis and the median inhibitory dose $\left(\mathrm{IC}_{50}\right)$ was evaluated by cytotoxicity test on two different cell lines. To estimate the cytotoxicity of each of the cell suspensions, $5 \times 10^{4}$ cells were seeded in 96-well flat bottom plate containing DMEM with $5 \%$ FBS and different concentrations of the green nanoparticles $(3.1,6.2,12.5,25,50,100 \mu \mathrm{g} / \mathrm{mL})$ were added to the plate and incubated at $37^{\circ} \mathrm{C}$ for $24 \mathrm{~h}$ in $5 \% \mathrm{CO}_{2}$ incubator. After incubation cells were washed with serum free medium and $100 \mathrm{~mL}$ of $5 \mathrm{mg} / \mathrm{mL}$ MTT was added and incubated for $4-5 \mathrm{~h}$. The incubated cells were washed with phosphate saline buffer, $100 \mu \mathrm{L}$ of DMSO was added to solubilize unbound formazan, and later the plates were read at $570 \mathrm{~nm}$ absorbance in a plate reader (Biotech, USA). The whole experiment was performed in triplicates and the concentration of $50 \%$ inhibition was determined by the color intensity formazan dye which will be proportional to the viable cells.

\subsection{Cell Cycle Analysis}

Cells were grown in 6-well plates at a density of $5 \times 10^{6}$ cells/well and treated with SNMC at different concentrations. Cells were harvested after $24 \mathrm{~h}$ by trypsinization, washed twice with phosphate buffer saline, and gently fixed with $95 \%$ ice cold ethanol overnight. Before further experiment, it was resuspended in PBS containing RNase $(0.5 \mu \mathrm{g} / \mathrm{mL})$ and stained with $1 \mathrm{ml}$ of propidium iodide $(50 \mu \mathrm{g} / \mathrm{mL})$ for $15 \mathrm{~min}$. DNA content was analyzed in a flow cytometer (FACS_ARIA II, Biosciences) using FACS Diva software.

\subsection{Western Blotting for aldose reductase (AR) Expression and Related Signaling Pathways}

For protein expression, cells were extracted using a protein extraction reagent (T-Per, Thermo fisher.) and normalized using the BCA (bicinchoninic acid) assay kit (Epitomics, Inc., Burlingame, CA, USA). The equal amount of proteins were separated on SDS-PAGE and transferred to the PVDF membrane (semidry blot film, BioRad, semi dry blot). Membranes were blocked using 10\% skimmed milk at $37{ }^{\circ} \mathrm{C}$ for $1-2 \mathrm{~h}$, the specific primary antibodies (1:2000) were exposed to the membranes at $4{ }^{\circ} \mathrm{C}$ overnight. The specific HRP-conjugated (anti-rabbit IgG) secondary antibodies (1:5000) were added for $1-2 \mathrm{~h}$ incubation at room temperature. $\beta$-actin was used as the reference marker for normalization. The protein expression was quantified using Quantity-One software to rate the expression of target proteins. 


\section{Quantitative RT-PCR}

Culture cells were harvested by trypsinization, and RNA was isolated by TRIzol using the method developed by Chomczynski and Sacchi (1987). RNA was washed in $1 \mathrm{ml}$ ethanol and dissolved in $50 \mu \mathrm{L}$ of $0.1 \%$ Diethyl pyrocarbonate (DEPC) treated water and stored at $-80^{\circ} \mathrm{C}$ until next use. The amount of RNA was quantified from its absorbance at $260 \mathrm{~nm}$ using a nanodrop. A sample of $5 \mu \mathrm{g}$ RNA was used to amplify the cDNA via reverse transcription using cDNA synthesis kits (Thermo fisher) and real time RT-PCR was done in StepOne Plus thermocycler (applied Biosystem), using SYBER Green PCR Master Mix. The primers used in this study are presented in Table 1, as described in literature. Quantitative fold change was calculated relative to control using comparative $\mathrm{Ct}$ method. The endogenous control used was GAPDH, the $\mathrm{Ct}$ values from each sample were calculated by subtracting the $\mathrm{Ct}$ value for GAPDH from that target gene.

Table 1. Primer details used in this study.

\begin{tabular}{|c|c|c|c|}
\hline S.No & Target Gene & & Sequences \\
\hline \multirow[t]{2}{*}{1} & Akt & Forward $\left(5^{\prime}-3^{\prime}\right)$ & CCATGAAGATTCAAGA \\
\hline & & Reverse $\left(5^{\prime}-3^{\prime}\right)$ & AGCGTAATCTAACATC \\
\hline \multirow[t]{2}{*}{2} & AR & Forward $\left(5^{\prime}-3^{\prime}\right)$ & CCTTTCATCGTGCAAGCT \\
\hline & & Reverse $\left(5^{\prime}-3^{\prime}\right)$ & TTTCACCAGCCTCATCC \\
\hline \multirow[t]{2}{*}{3} & c-Myc & Forward $\left(5^{\prime}-3^{\prime}\right)$ & ТСТТССССТАСТСТСААС \\
\hline & & Reverse $\left(5^{\prime}-3^{\prime}\right)$ & ССТCATCTTCGTTCСTCСTC \\
\hline \multirow[t]{2}{*}{4} & CREB & Forward $\left(5^{\prime}-3^{\prime}\right)$ & ACAGTATTGATTACCCAGG \\
\hline & & Reverse $\left(5^{\prime}-3^{\prime}\right)$ & CTGTGCGAATCTTATGTTTG \\
\hline \multirow[t]{2}{*}{5} & ERK & Forward $\left(5^{\prime}-3^{\prime}\right)$ & GATTGCTGACTGAGCAC \\
\hline & & Reverse $\left(5^{\prime}-3^{\prime}\right)$ & GGGGGCCTCTTGCC \\
\hline \multirow[t]{2}{*}{6} & IkB- $\alpha$ & Forward $\left(5^{\prime}-3^{\prime}\right)$ & GGACCCCACCAAAATCG \\
\hline & & Reverse $\left(5^{\prime}-3^{\prime}\right)$ & TCAGGCGCGGAATTTCC \\
\hline \multirow[t]{2}{*}{7} & NF-kB p65 & Forward $\left(5^{\prime}-3^{\prime}\right)$ & GAAGAAGCGAGATGGAGCAA \\
\hline & & Reverse $\left(5^{\prime}-3^{\prime}\right)$ & GTTGATGGTGCAGGGATGCT \\
\hline \multirow[t]{2}{*}{8} & PI3K & Forward $\left(5^{\prime}-3^{\prime}\right)$ & TTAAACGCGGGCAACGA \\
\hline & & Reverse $\left(5^{\prime}-3^{\prime}\right)$ & CAGTCTCCTTGCTGTCGAT \\
\hline \multirow[t]{2}{*}{9} & IkkB & Forward $\left(5^{\prime}-3^{\prime}\right)$ & GAGTTTGGCCACATCG \\
\hline & & Reverse $\left(5^{\prime}-3^{\prime}\right)$ & GCCACACCATCTTCTA \\
\hline \multirow[t]{2}{*}{10} & GAPDH & Forward $\left(5^{\prime}-3^{\prime}\right)$ & ACCACAGTATGCCATCAC \\
\hline & & Reverse $\left(5^{\prime}-3^{\prime}\right)$ & TCCACCACTGTTGCTGTA \\
\hline
\end{tabular}

\section{Results}

The as-synthesized silver nanoparticles using Myrtus communis L. extract (Ag-MC) was carried under reflux circumstances. The confirmation of silver ions reduction was noticed by the evident color transformation of the reaction mixture from light yellow to dark brown. Primarily, the confirmation of AgNPs formation was carried out by UV-Vis analysis, which is an important approach to notice the development and stability of Ag-MC. In this case, the absorption spectra of pure Myrtus communis L. extract (MC) and green synthesized AgNPs (Ag-MC) prepared by using a volume of $1 \mathrm{~mL}$ plant extract was measured as shown in Figure 1. The UV-Vis analysis of the green synthesized Ag-MC clearly reflected the sharp intensities of the absorption band at $\sim 420 \mathrm{~nm}$. The absorption band intensities at 275 and $320 \mathrm{~nm}$ in Ag-MC, demonstrate that the Myrtus communis L. extract not only acts as a reducing and capping agent, but also that the phytoconstituents of MC functionalized the surface of Ag-MC. 


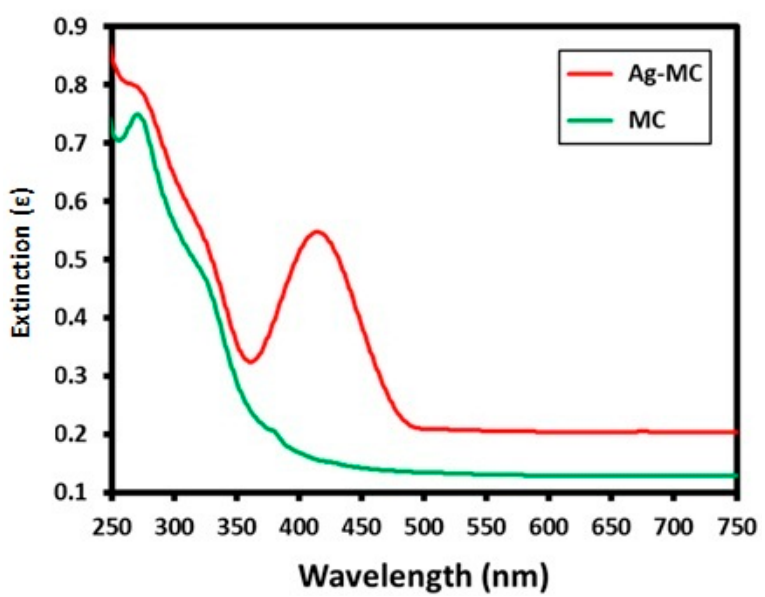

Figure 1. UV-Vis spectra of pure Myrtus communis L. plant extract (MC) and green synthesized silver nanoparticles using Myrtus communis L. extract (Ag-MC).

The plant extract dual role as a green reductant and stabilizing or capping agent was proved by associating the FT-IR spectra of pure Myrtus communis L. extract and green synthesized silver nanoparticles (Ag-MC) as presented in Figure 2. In order to eliminate any probability of the occurrence of residual unbounded phytomolecules on the surface of the Ag-MC, the filtered Ag-MC were redispersed in deionized water via sonication for $30 \mathrm{~min}$. After that, the Ag-MC was isolated through centrifugation for $30 \mathrm{~min}$ at a speed of $8000 \mathrm{rpm}$. A similar procedure was continued three times to isolate pure as-synthesized AgNPs (Ag-MC). As displayed in Figure 3, the Ag-MC is similar to the FT-IR spectrum of plant extract (MC), apart from insignificant shifts in some peaks. This similarity among the two FT-IR spectrums indicate that some of the phytoconstituents of plant extracts exist on the surface of the as-synthesized Ag-MCs. This clearly indicates that the plant extract acts as both a reducing and stabilizing agent. The Myrtus communis L. extract displayed numerous absorption peaks at dissimilar positions like the peak at $\sim 3420 \mathrm{~cm}^{-1}$ corresponding to hydroxy group $\sim 2920$ and $\sim 2850 \mathrm{~cm}^{-1}$ corresponds to $-\mathrm{CH}$ symmetrical and asymmetrical stretch, $2150 \mathrm{~cm}^{-1}$ corresponds to $\mathrm{C} \equiv \mathrm{C}$ stretch, $1710 \mathrm{~cm}^{-1}$ corresponds to carbonyl stretch $\mathrm{C}=\mathrm{O}, 1380$ and $1030 \mathrm{~cm}^{-1}$ corresponds to $\mathrm{C}-\mathrm{O}$ stretch which is associated to several oxygen comprising functional groups. Most of these peaks exist with a marginal shift in the FT-IR spectrum of AgNPs (Ag-MC). This proves the existence of these peaks in both MC and Ag-MC, evidently signifying the tiny role of Myrtus communis L. extract as a bioreducing and stabilizing agent.

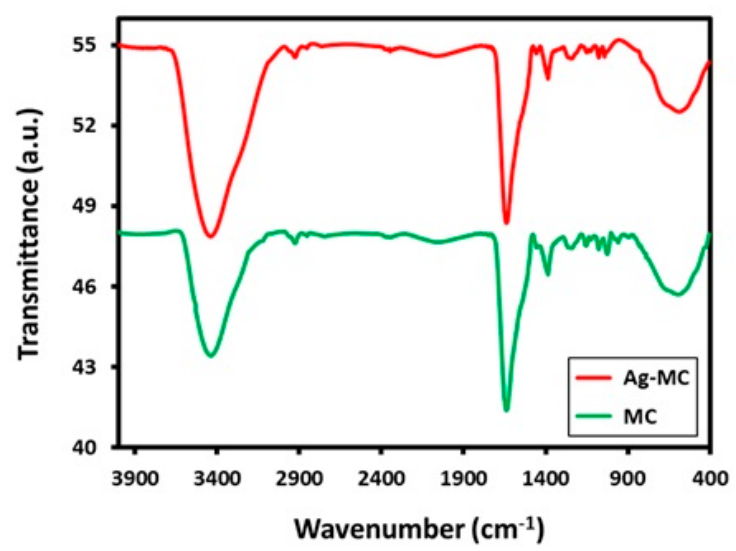

Figure 2. FT-IR spectra of pure Myrtus communis L. plant extract (MC) and green synthesized silver nanoparticles using Myrtus communis L. extract (Ag-MC). 


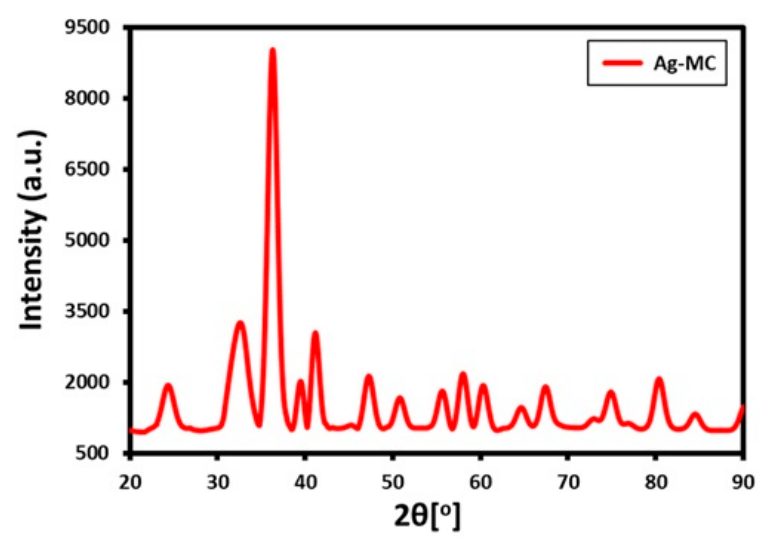

Figure 3. XRD diffractogram of green synthesized silver nanoparticles using Myrtus communis L. extract $(\mathrm{Ag}-\mathrm{MC})$.

The as-synthesized Ag-MC was confirmed by XRD analysis. The diffractogram of Ag-MC showed numerous intense diffractions (Figure 3), which not only proved the crystallinity of the silver nanoparticles, but also indicated the identities of the AgNPs. Especially the five separate reflections at $37.5^{\circ}(111), 44.1^{\circ}(200), 64.3^{\circ}(220), 76.8^{\circ}(311)$ and $81.2^{\circ}(222)$, evidently endorsed the structure of $\mathrm{Ag}-\mathrm{MC}$ face-centered cubic (fcc) structure. However, in the XRD spectrum of Ag-MC extra reflections were also noticed distant from the reflections associated to Ag-MC (Figure 4). These XRD spectrum showed extra peak reflections in nanoparticles and endorsed the existence of residual phytoconstituents from the Myrtus communis L. extract on the surface of Ag-MC. The shape and size of the as-synthesized Ag-MCs using $1 \mathrm{ml}$ of Myrtus communis L. extract were assessed by TEM analysis. Figure 4a exhibits the size within the range of 20-30 nm and the spherical morphology of the Ag-MC. Some of the Ag-MC were uniformly distributed, while a few of them were observed to be agglomerated. The Ag-MC elemental composition analysis was investigated by EDX analysis. The sharp signal at $3 \mathrm{keV}$ firmly recommended that silver was the major element and the signal at $0.0-0.5 \mathrm{keV}$ was associated to the absorption of carbon and oxygen. This signal clearly specified the occurrence of the phytomolecules from the Myrtus communis L. extract existing on the surface of the as-synthesized Ag-MC as a stabilizing agent.
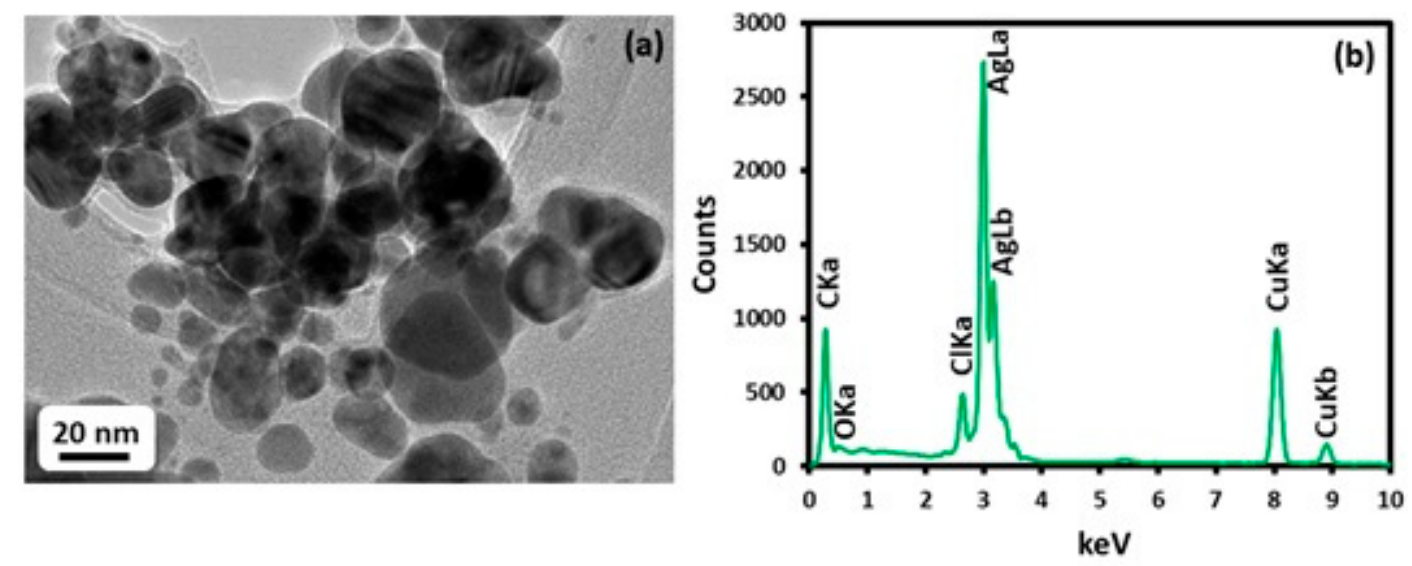

Figure 4. (a) high resolution transmission electron microscopy (HRTEM) image of the green synthesized silver nanoparticles (Ag-MC), and (b) energy dispersive X-ray spectroscopy of Ag-MC.

\subsection{Effect of Ag-MC on Cell Viability}

The in-vitro cell proliferation (MTT assay) was evaluated to detect the anti-proliferative activity of green synthesized nanoparticles Ag-MC on two different cancer cell lines. As illustrated in Figure 5, Silver nanoparticles showed significant proliferation inhibition within HepG2 cells with $\mathrm{IC}_{50}$ of $(7.75 \mu \mathrm{M} / \mathrm{mL})$, and Hela cells showed moderate proliferation inhibition at $\mathrm{IC}_{50}$ of $30.6 \mu \mathrm{M} / \mathrm{mL}$. 
The effect of MC and Ag nanoparticles were comparatively less effective than Ag- MC combined. As evident in Figure 5, the Ag-MC combined nanoparticle had a more profound inhibitory effect on both of the cell lines. We further experimented using only Ag-MC as the tests were costly and we did not intend to further compare the results. The cytotoxicity test was a good indication that Ag-MC had better inhibition. The results of the two tested cancer cell lines showed anti-proliferative activity, and HepG2 cells gave a better response. The response improved considerably when checked at $24 \mathrm{~h}$ of treatment. Concentration above $128 \mu \mathrm{M} / \mathrm{mL}$ of Ag-MC was able to inhibit $80 \%$ of growth for HepG2 cells.
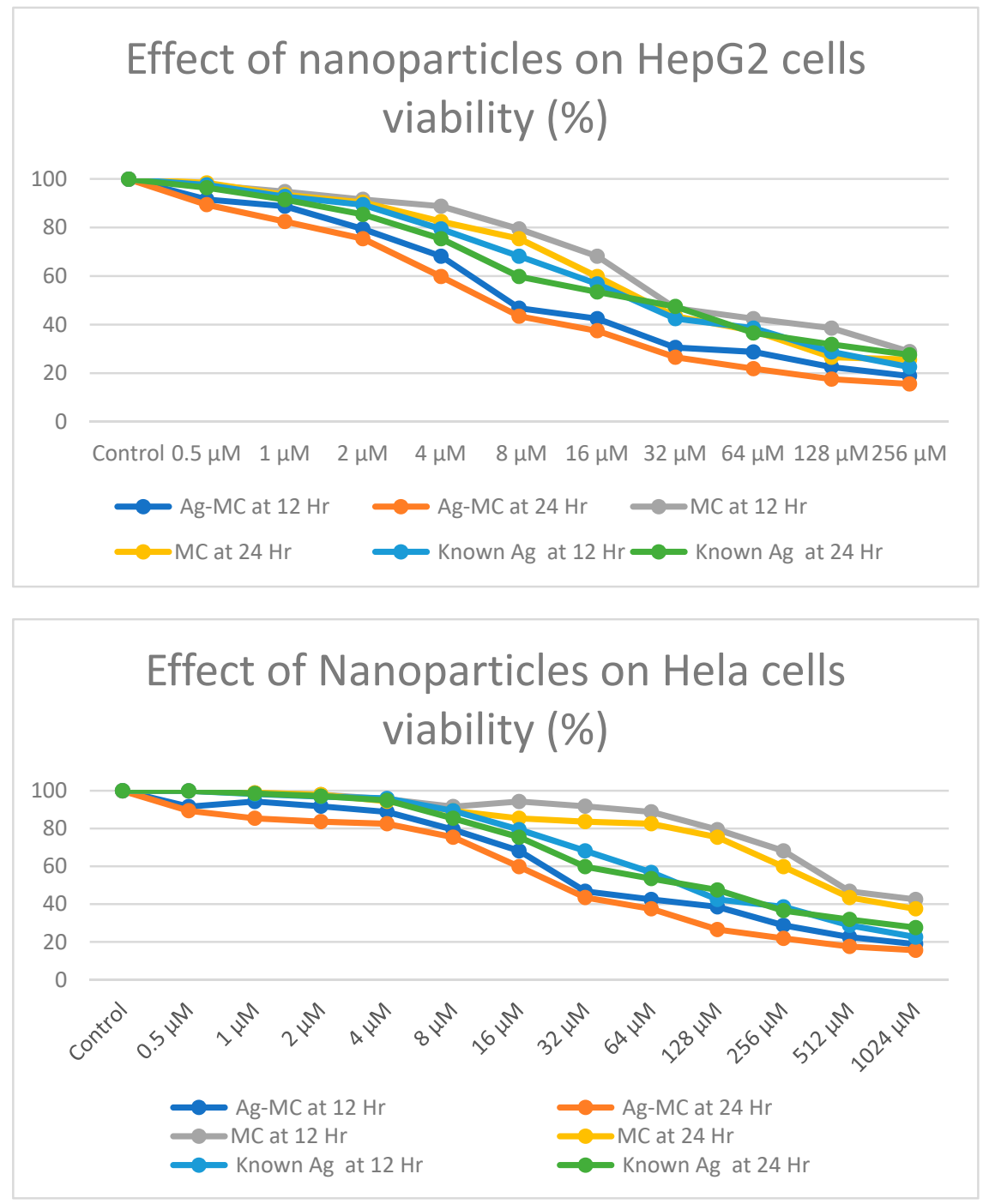

Figure 5. Effect of Ag-MC on HepG2 and Hela cells viability (\%).

\subsection{Influence of $A g-M C$ on $A R$ Expression and Abrogation of PI3K/Akt/mTOR Signalling}

The effect of Ag-MC on aldose reductase (AR) expression was determined on HepG2 cell line. Treatment of Ag-MC significantly reduced the AR expression compared to control (Figure 6), and at concentration of $7.5 \mu \mathrm{M} / \mathrm{mL}$ the AR expression was below $50 \%$ of control. The protein expression of MAPK pathway related components PI3K and AKT was also evaluated. Treatment with Ag-MC significantly reduced the mRNA expression of PI3K and Akt as well as the protein expression of PI-3 kinase, Akt and mTOR (Figure 7) compared to untreated cells. 


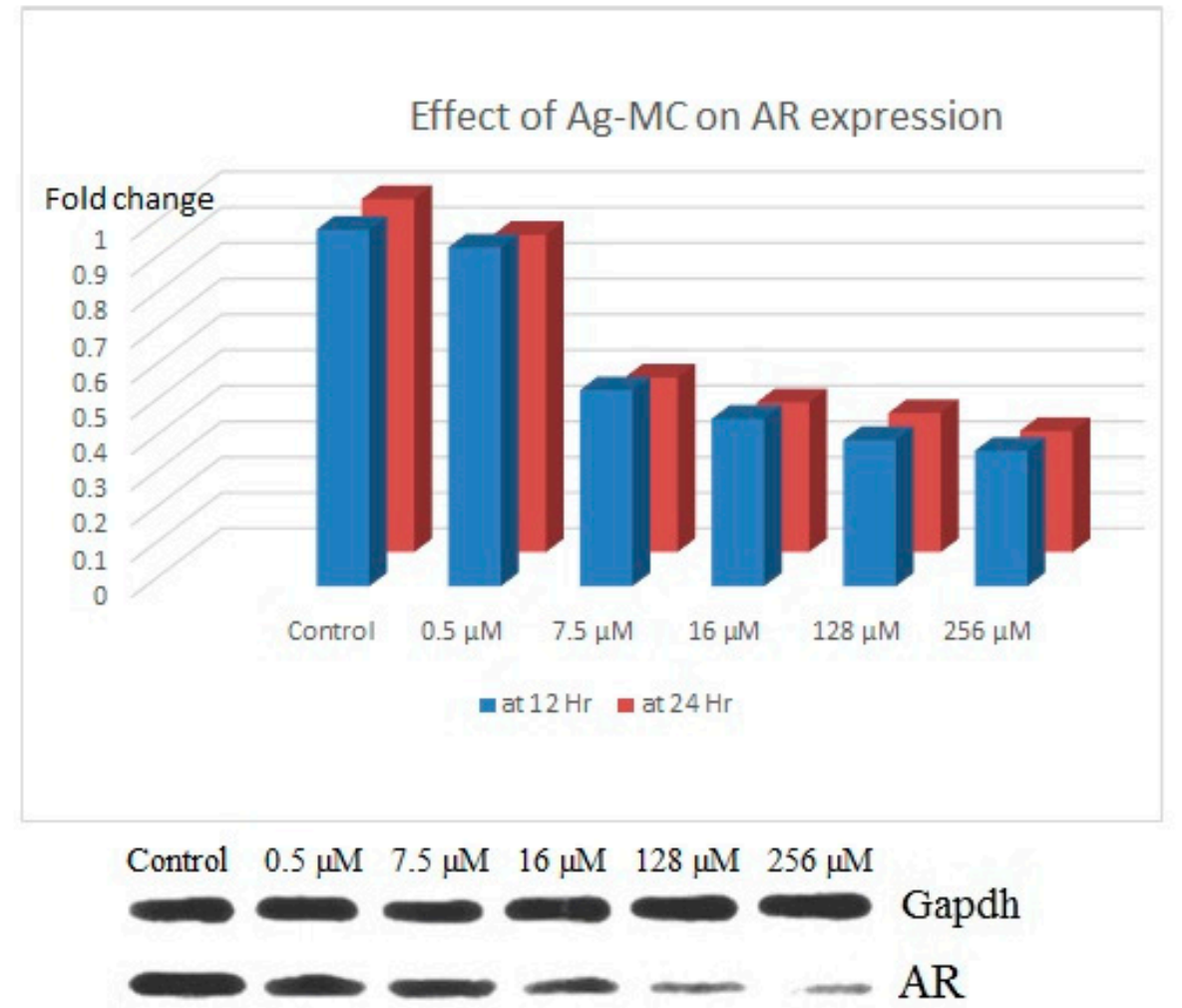

HepG2

Figure 6. Effect of Ag-MC $(0.5 \mu \mathrm{M}$ to $256 \mu \mathrm{M})$ on AR protein expression.

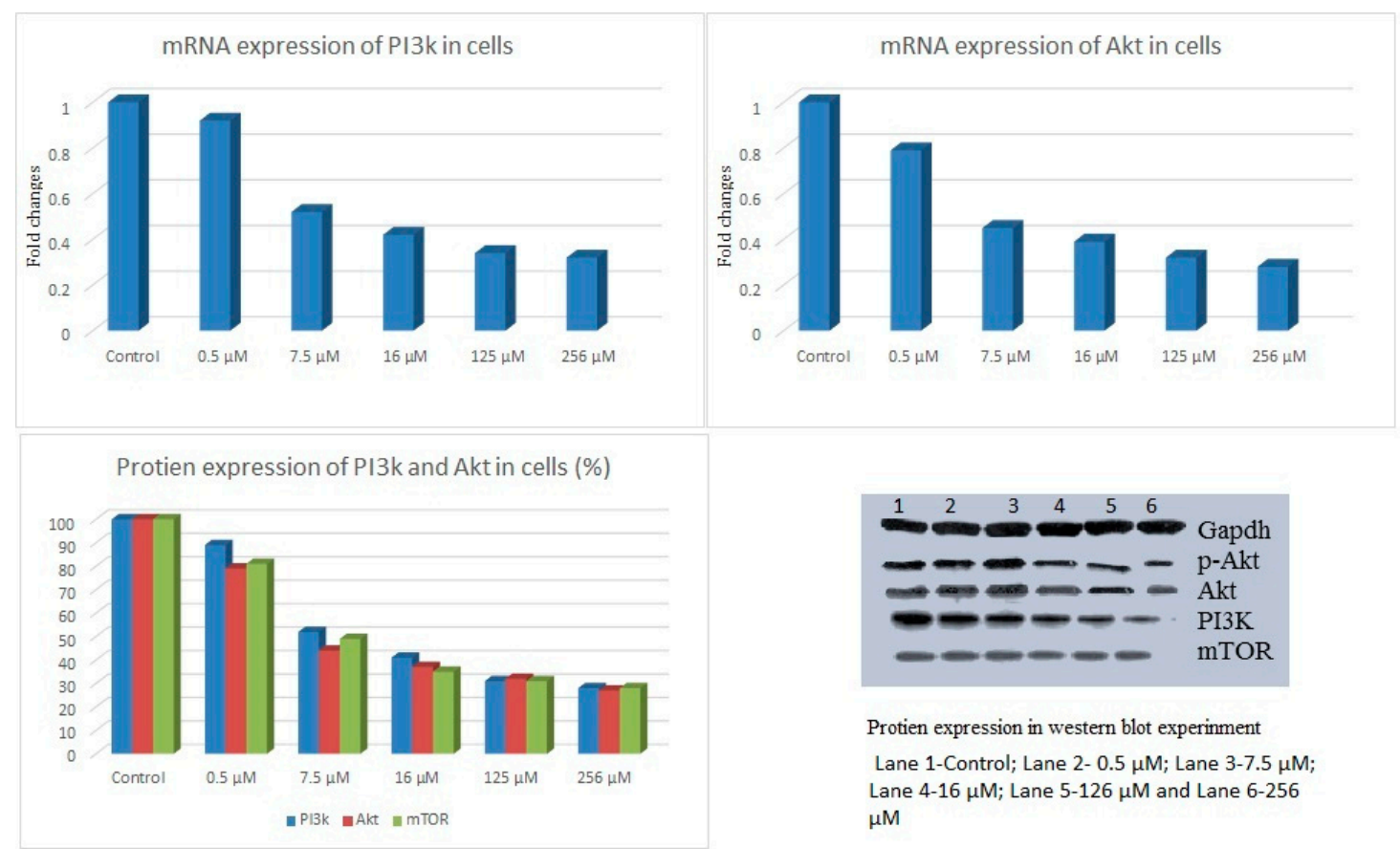

Figure 7. Effect of Ag-MC on mRNA and protein expression of MAPK signaling molecules.

\subsection{Ag-MC Impedes ERK Signaling}

The ERK expression was analyzed by qRT-PCR and immunoblotting. Results indicated that $\mathrm{Ag}-\mathrm{MC}$ treatment down regulated the expression of p-ERK1/2 compared to untreated cells. C-Myc and 
p-CREB expression were also decreased significantly (Figure 8a). The expression of p-ERK1 was not that significant and comparatively less than c-Myc, p-CREB and CREB. Western blot showed a similar outcome in support of the above experiment thus confirming that Ag-MC hampered ERK signaling in a dose dependent manner (Figure 8 b).

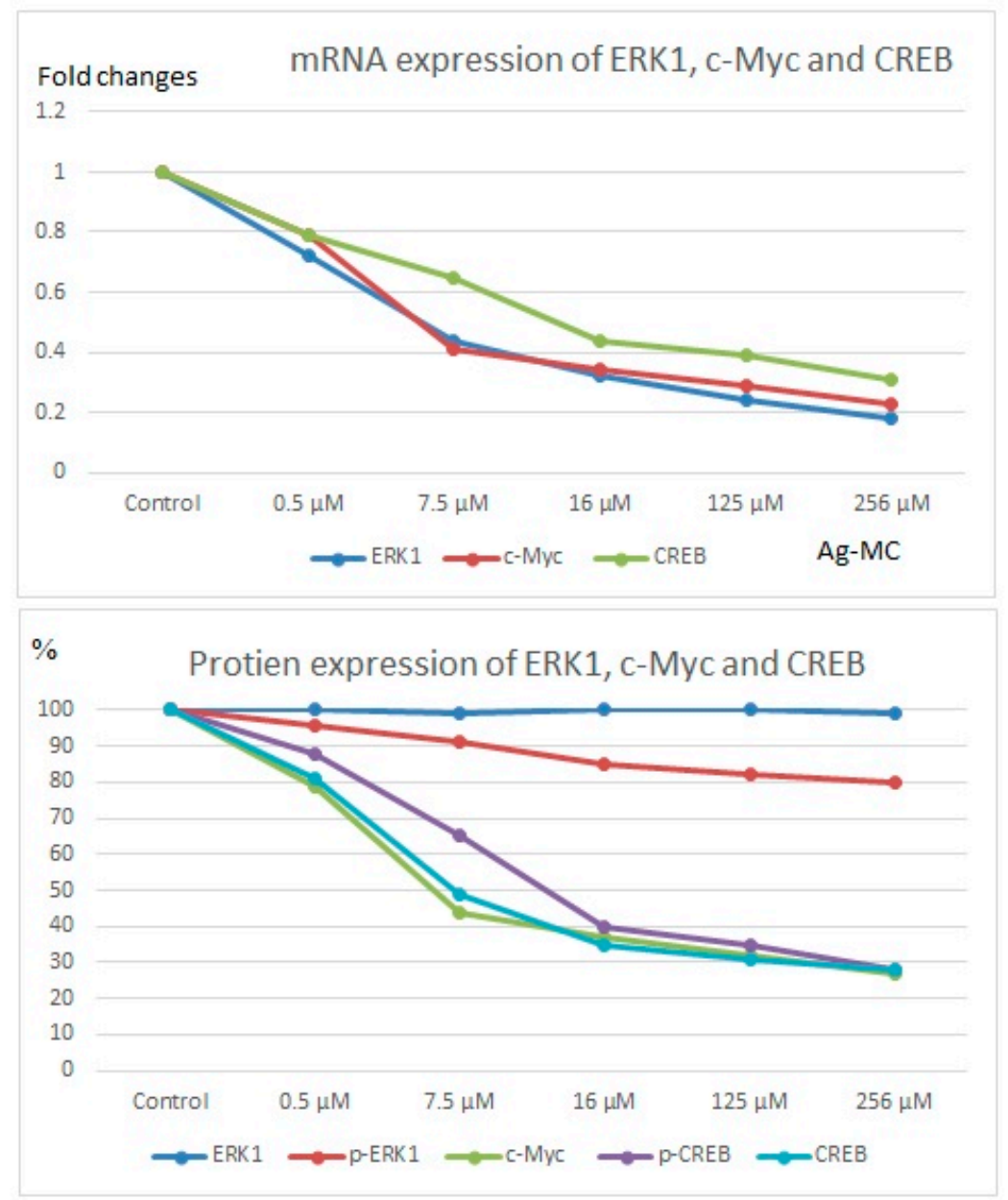

(a)

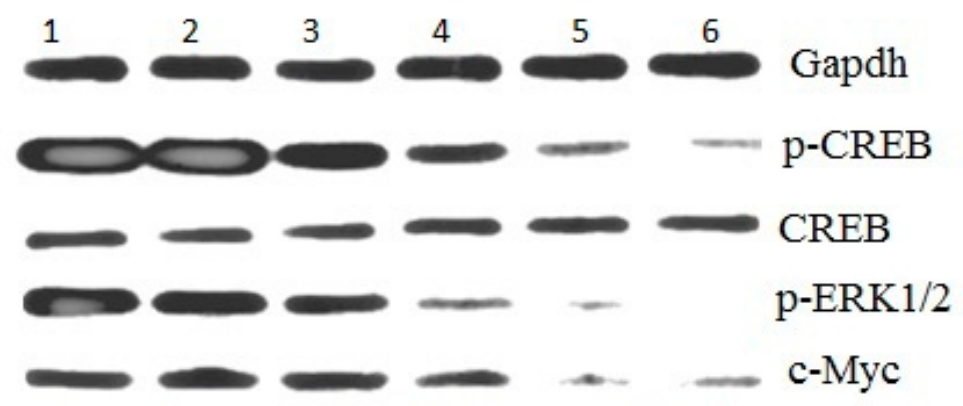

Lane 1-Control; Lane 2- 0.5 $\mu \mathrm{M}$; Lane 3-7.5 $\mu \mathrm{M}$; Lane 4-16 $\mu \mathrm{M}$; Lane 5-126 $\mu \mathrm{M}$ and Lane 6-256 $\mu \mathrm{M}$

(b)

Figure 8. $(\mathbf{a}, \mathbf{b})$ Effect of Ag-MC on mRNA and protein expression of ERK signaling molecules. 


\subsection{Ag-MC Inhibits the NF-kB Signaling}

Ag-MC treatment significantly decreased the expression of IKK $\beta, p-I k \beta \alpha, N F-k \beta p 50$ and NF-k $\beta$ p65 and at the same time increased the expression of $\operatorname{Ik} \beta \alpha$. This study also found that Ag-MC treatment effectively inhibited the phosphorylation of NF-k $\beta$ p65, preventing NF-kB p65 translocation (Figure 9a,b). Cell cycle analysis by flow cytometry showed an increase in the accumulation of cells in the SubG0/G1 phase and depletion of cells in the $S$ and G2/M phases indicating a cell arrest at G1/S phase (Figure 10). Cell cycle dependent key molecules were examined under the influence of Ag-MC treatment and the study found an increase in the expression of p-cyclin D1, p21 with a simultaneous decrease in the expression of PCNA (data not shown).
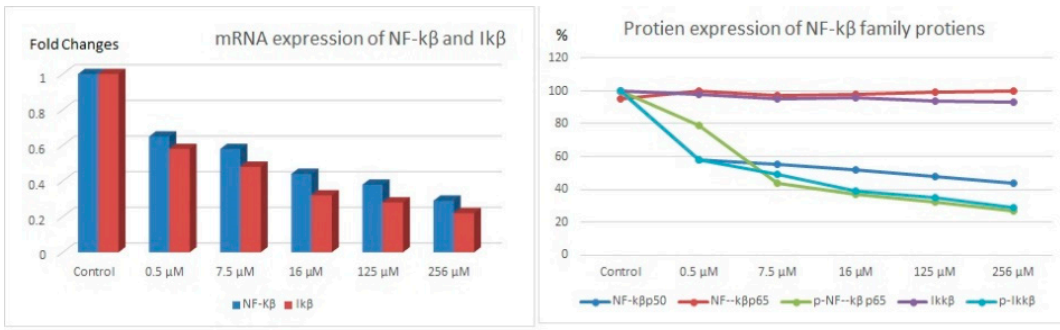

(a)

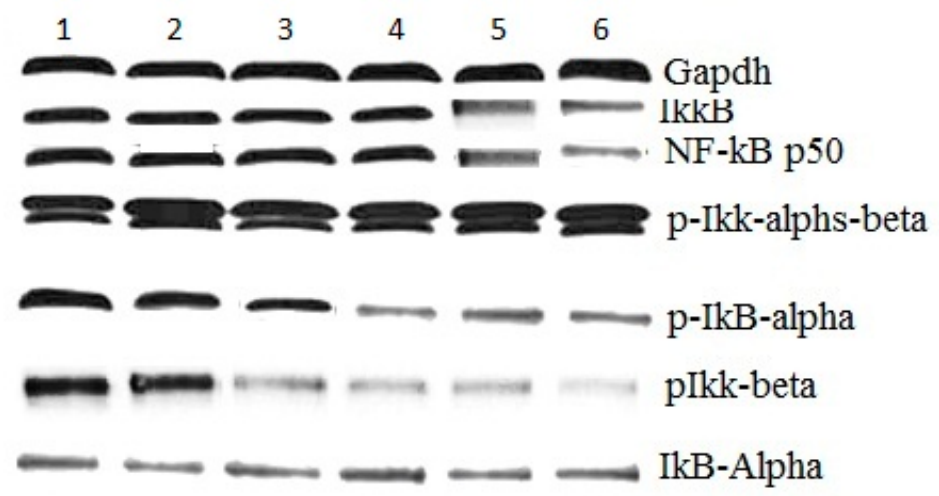

Lane 1-Control; Lane 2- 0.5 $\mu \mathrm{M}$; Lane 3-7.5 $\mu \mathrm{M}$; Lane 4-16 $\mu \mathrm{M}$; Lane 5-126 $\mu \mathrm{M}$ and Lane 6-256 $\mu \mathrm{M}$

(b)

Figure 9. $(\mathbf{a}, \mathbf{b})$ Effect of Ag-MC on protein expression of NF-k $\beta$ family proteins.
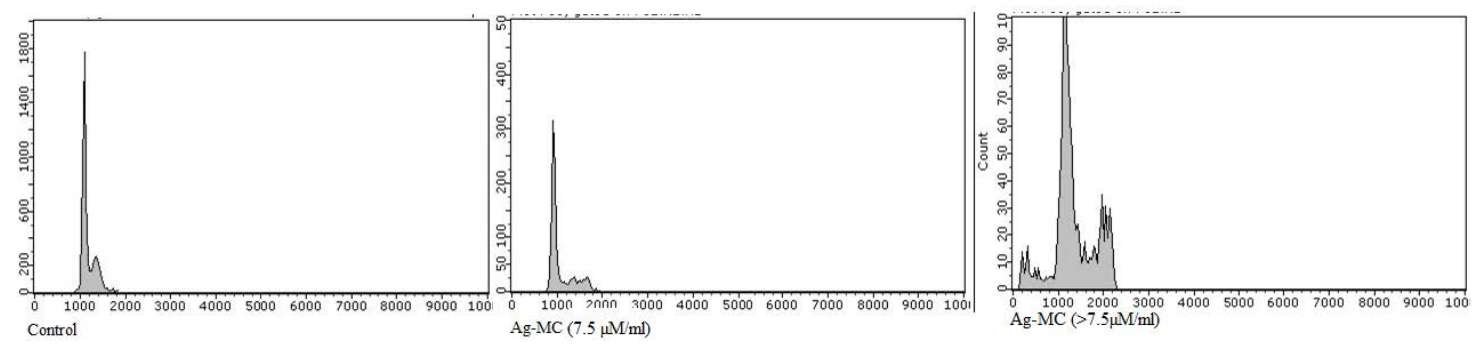

Figure 10. Cell cycle analysis in flow cytometer.

\section{Discussion}

Since ancient times to the present day, plants and their derivatives are valuable resources for all kinds of medicine and food and it is simply impossible to manufacture any kind of drug without using any phytochemicals [21]. In the treatment of cancer and various other diseases, bioactive compounds-especially from plant sources-play a pivotal role in treatments and finding new drugs. From our findings, M. cummunis showed consistent anticancer activity as tested in vitro in cell lines. 
A previous study from Yemen confirmed that methanolic extract of MC has significant anticancer activity, tested against MCF7 cell lines [22]. Not only the crude and alcoholic extracts from $M$. cummunis, but also the essential oil showed good activity, tested in breast cancer cell lines during the screening study conducted at the cancer research institute at Brigham Young University [23]. It is well documented that more than $60 \%$ of synthetic drugs that we use in our routine life are from natural origin, like a plant source [24], and 50\% products used in the treatment process are acquired from natural habitats., and for these reasons, medicinal plants were considered as an important resource for natural bioactive compounds [25].

Green nanotechnology is the utilization of various plant resources for the biosynthesis of metallic nanoparticles. "Green synthesis" of nanoparticles makes use of environmentally friendly and non-toxic reagents. This amplifies the growing need to develop environment friendly processes through green synthesis and other biological approaches. Our current approach targeted the biological application of silver nanoparticles from $M$. cummunis using green synthesis. The results were favorable for the use of these plants as source for adjuvant or alternative medicine. More research has to be focused on developing ecofriendly and low cost drugs using natural products. Treatment of cancer cell line with Ag-MC inhibited the cell growth in dose dependent manner. There is no earlier study demonstrating the anticancer effect of Ag-MC. Reactive oxygen species plays a major role in the activation of oncogenic signaling pathways which include AR, ERK and NF-k $\beta$. Extensive generation of ROS has a pronounced effect on cell survival and anti-apoptotic process. Inhibition of ROS in cancer cell lines via natural or synthetic products are being evaluated. In cancer cells AR is overexpressed, and inhibition of AR is an effective way to control proliferation of cancer cell lines. Down regulation of PI3K/Akt, ERK, $\mathrm{NF}-\mathrm{k} \beta$ and proteins involved in cell cycle progression was abrogated in the presence of Ag-MC and the cell cycle was arrested by targeting AR. Inhibition of AR induced the apoptosis via upregulation of cell death receptor expression [26-29]. AR inhibition down regulated growth factor induced cancer growth by upregulating expression of programmed cell death 4 (PDCD4) [27-29]. Down regulation of CREB, anti-apoptotic proteins and upregulation of pro-apoptotic proteins were observed when cancer cells were treated with SNMC, which induced the apoptosis process via inhibition of AR and associated networks.

\section{Conclusions}

Myrtus communis L. is widely used in unani medicine, known for its rich contents of flavonoids, alkaloids, tannins, terpenoids and saponins, which seem to have antioxidants and are likely to have anticancer properties. There are no previous reports on the inhibitory effect of Myrtus communis L. extract in in vitro and in vivo models. Therefore the effect on the oncogenic signaling pathways and cancer hallmarks has not been analyzed before. This present study demonstrated the therapeutic potential of silver nanaoparticles of Myrtus communis L. extract and presume that AR inhibition could be a key factor for its anticancer effect. The inhibition of AR could set off a cascade of events, inactivation of oncogenic kinases and transcription factors.

Author Contributions: Designed this study and worked in molecular part of the manuscript, A.A.A. (Abdulwahab Ali Abuderman) and R.S.; Extracted and isolated GNPs from plant sample, A.A.A. (Abdullah A. Alyousef); Executed characterization of AgNPs, M.S.A. and M.S.O.; Worked in cell culture and molecular assays, R.S. and A.K.; Involved in lab assays and done statistical analysis, M.S.O. and R.S.; All the authors were involved in preparation, review and submitting the article.

Funding: This research was funded by the Research Groups Program (Research Group number RG-1440-070) and The APC was funded by Deanship of Scientific Research, King Saud University, Riyadh, Saudi Arabia.

Acknowledgments: This project was supported by the Research Groups Program (Research Group number RG-1440-070), Deanship of Scientific Research, King Saud University, Riyadh, Saudi Arabia.

Conflicts of Interest: The authors declare that they have no conflict of interest. 


\section{References}

1. Rafique, M.; Sadaf, I.; Rafique, M.S.; Tahir, M.B. A review on green synthesis of silver nanoparticles and their applications. Artif. Cells Nanomed. Biotechnol. 2017, 45, 1272-1291. [CrossRef] [PubMed]

2. Kumal, R.R.; Abu-Laban, M.; Landry, C.R.; Kruger, B.; Zhang, Z.; Hayes, D.J.; Haber, L.H. Plasmon-enhanced photocleaving dynamics in colloidal microRNA-functionalized silver nanoparticles monitored with second harmonic generation. Langmuir 2016, 32, 10394-10401. [CrossRef] [PubMed]

3. Kumal, R.R.; Abu-Laban, M.; Hamal, P.; Kruger, B.; Smith, H.T.; Hayes, D.J.; Haber, L.H. Near-Infrared Photothermal Release of siRNA from the Surface of Colloidal Gold-Silver-Gold Core-Shell-Shell Nanoparticles Studied with Second-Harmonic Generation. J. Phys. Chem. C 2018, 122, 19699-19704. [CrossRef] [PubMed]

4. Sadowski, Z.; Maliszewska, I.; Grochowalska, B.; Polowczyk, I.; Kozlecki, T. Synthesis of silver nanoparticles using microorganisms. Mate. Sci. Pol. 2008, 26, 419-424.

5. Asmathunisha, N.; Kathiresan, K. A review on biosynthesis of nanoparticles by marine organisms. Colloids Surf. B 2013, 103, 283-287. [CrossRef]

6. Sanghi, R.; Verma, P. Biomimetic synthesis and characterisation of protein capped silver nanoparticles. Bioresour. Technol. 2009, 100, 501-504. [CrossRef]

7. Chakraborty, I.; Parak, W.J. Protein-Induced Shape Control of Noble Metal Nanoparticles. Adv. Mater. Interfaces 2019, 6, 1801407. [CrossRef]

8. Shaik, M.R.; Ali, Z.J.Q.; Khan, M.; Kuniyil, M.; Assal, M.E.; Alkhathlan,H.Z.; Al-Warthan, A.; Siddiqui, M.R.H.; Khan, M.; Adil, S.F. Green Synthesis and Characterization of Palladium Nanoparticles Using Origanum vulgare L. Extract and Their Catalytic Activity. Molecules 2017, 22, 165. [CrossRef]

9. Ranoszek-Soliwoda, K.; Tomaszewska, E.; Małek, K.; Celichowski, G.; Orlowski, P.; Krzyzowska, M.; Grobelny, J. The synthesis of monodisperse silver nanoparticles with plant extracts. Colloids Surf. B 2019, 177, 19-24. [CrossRef]

10. Anandan, M.; Poorani, G.; Boomi, P.; Varunkumar, K.; Anand, K.; Chuturgoon, A.A.; Saravanan, M.; Prabu, H.G. Green synthesis of anisotropic silver nanoparticles from the aqueous leaf extract of Dodonaea viscosa with their antibacterial and anticancer activities. Process Biochem. 2019, 80, 80-88. [CrossRef]

11. Khan, M.; Khan, M.; Adil, S.F.; Tahir, M.N.; Tremel, W.; Alkhathlan, H.Z.; Al-Warthan, A.; Siddiqui, M.R.H. Green synthesis of silver nanoparticles mediated by Pulicaria glutinosa extract. Int. J. Nanomed. 2013, 8, 1507.

12. Mintah, S.O.; Asafo-Agyei, T.; Archer, M.A.; Junior, P.A.A.; Boamah, D.; Kumadoh, D.; Appiah, A.; Ocloo, A.; Boakye, Y.D.; Agyare, C. Medicinal Plants for Treatment of Prevalent Diseases. In Pharmacognosy-Medicinal Plants; IntechOpen: London, UK, 2019.

13. Chitme, H.R.; Chandra, M.; Kaushik, S. Studies on anti-diarrhoeal activity of Calotropis gigantea R.Br. in experimental animals. J. Pharm. Pharm. Sci. 2004, 7, 70-75. [PubMed]

14. Kim, H.S. Do not put too much value on conventional medicines. J. Ethnopharmacol. 2005, 100, 37-39. [CrossRef] [PubMed]

15. Sumbul, S.; Ahmad, M.A.; Asif, M.; Akhtar, M. Myrtus Communis Linn.-A Review. Indian J. Nat. Product. Resour. 2011, 2, 395-402.

16. Sisay, M.; Gashaw, T. Ethnobotanical, ethnopharmacological, and phytochemical studies of Myrtus communis Linn: A popular herb in Unani system of medicine. J. Evid. Based Complement. Altern. Med. 2017, 22, 1035-1043. [CrossRef]

17. Shahat, A.S.; Assar, N.H. Biochemical and antimicrobial studies of biosynthesized silver nanoparticles using aqueous extract of Myrtus communis L. Ann. Biol. Res. 2015, 6, 90-103.

18. Alipour, G.; Dashti, S.; Hosseinzadeh, H. Review of pharmacological effects of Myrtus communis L. and its active constituents. Phytother. Res. 2014, 28, 1125-1136. [CrossRef]

19. Alamanni, M.; Cossu, M. Radical scavenging activity and antioxidant activity of liquors of myrtle (Myrtus communis L.) berries and leaves. Ital. J. Food Sci. 2004, 16, 197-208.

20. Akin, M.; Aktumsek, A.; Nostro, A. Antibacterial activity and composition of the essential oils of Eucalyptus camaldulensis Dehn. and Myrtus communis L. growing in Northern Cyprus. Afr. J. Biotechnol. 2010, $9,531-535$. 
21. Baker, J.T.; Borris, R.P.; Carté, B.; Cordell, G.A.; Soejarto, D.D.; Cragg, G.M.; Gupta, M.P.; Iwu, M.M.; Madulid, D.R.; Tyler, V.E. Natural product drug discovery and development: New perspectives on international collaboration. J. Nat. Prod. 1995, 58, 1325-1357. [CrossRef]

22. Mothana, R.A.; Kriegisch, S.; Harms, M.; Wende, K.; Lindequist, U. Assessment of selected Yemeni medicinal plants for their in vitro antimicrobial, anticancer, and antioxidant activities. Pharm. Biol. 2011, 49, 200-210. [CrossRef] [PubMed]

23. Schneidewind, H.; Schüler, T.; Strelau, K.K.; Weber, K.; Cialla, D.; Diegel, M.; Mattheis, R.; Berger, A.; Möller, R.; Popp, J. The morphology of silver nanoparticles prepared by enzyme-induced reduction. Beilstein J. Nanotechnol. 2012, 3, 404-414. [CrossRef] [PubMed]

24. Sunkar, S.; Nachiyar, C.V. Microbial synthesis and characterization of silver nanoparticles using the endophytic bacterium Bacillus cereus: A novel source in the benign synthesis. Glob. J. Med. Res. 2012, 12, 43-50.

25. Ogur, R. Studies with Myrtus communis L.: Anticancer properties. J. Intercult. Ethnopharmacol. 2014, 3, 135. [CrossRef]

26. Hanahan, D.; Robert, A.W. The hallmarks of cancer. Cell 2000, 100, 57-70. [CrossRef]

27. Balunas, M.J.; Kinghorn, A.D. Drug discovery from medicinal plants. Life Sci. 2005, 78, 431-441. [CrossRef]

28. Shoeb, M.; Ramana, K.V.; Satish, K.S. Aldose reductase inhibition enhances TRAIL-induced human colon cancer cell apoptosis through AKT/FOXO3a-dependent upregulation of death receptors. Free Radic. Biol. Med. 2013, 63, 280-290. [CrossRef]

29. Saxena, A.; Mohammad, S.; Kota, V.R.; Satish, K.S. Aldose reductase inhibition suppresses colon cancer cell viability by modulating microRNA-21 mediated programmed cell death 4 (PDCD4) expression. Eur. J. Cancer 2013, 49, 3311-3319. [CrossRef]

(C) 2019 by the authors. Licensee MDPI, Basel, Switzerland. This article is an open access article distributed under the terms and conditions of the Creative Commons Attribution (CC BY) license (http://creativecommons.org/licenses/by/4.0/). 